\title{
Pharmaciana
}

Vol.11, No.3,Nov 2021, Page. 427-438

ISSN: 2088 4559; e-ISSN: 24770256

\section{Composition of carbopol 940 and HPMC affects antibacterial activity of beluntas (Pluchea indica (L.)) leaves extract gel}

\author{
Fitra Alvionida ${ }^{1}$, Nanik Sulistyani ${ }^{* 2}$, Nining Sugihartini ${ }^{3}$ \\ ${ }^{1}$ Postgraduate Pharmacy Program in Development of Natural Medicines and Cosmetics, Faculty of Pharmacy, \\ Universitas Ahmad Dahlan \\ Jl.Prof. Dr. Soepomo, S.H., Warungboto, Umbulharjo, Yogyakarta, Indonesia \\ ${ }^{2}$ Departement of Pharmaceutical Biology, Faculty of Pharmacy, Universitas Ahmad Dahlan, \\ Jl. Prof. Dr. Soepomo, S.H., Warungboto, Umbulharjo, Yogyakarta, Indonesia \\ ${ }^{3}$ Departement of Pharmaceutical Technology, Faculty of Pharmacy, Universitas Ahmad Dahlan, \\ Jl Prof. Dr. Soepomo, S.H., Warungboto,Umbulharjo, Yogyakarta, Indonesia
}

\begin{abstract}
Indonesia is a country known for its source of biological wealth, one of which is beluntas leaves. Beluntas leaves have the potential to be an antibacterial, so it is appropriate to be formulated in the form of medicinal preparations, especially gels. This study aims to find out the influence of variations between carbopol gel base 940 and hydroxypropyl methylcellulose (HPMC) on the physical properties of gel preparations beluntas leaf extract (Pluchea indica (L.), and know the influence of gel of extract of beluntas leaves on antibacterial activity. The extract is obtained by the maceration method using ethanol solvent $96 \%$. Each formula uses $15 \%$ of the extract of beluntas leaves. Gels are made in four gel base variations namely F0 (0.5\% carbopol, $1 \%$ HPMC), FI (1\% carbopol, $1.5 \%$ HPMC), FII (1.5\% carbopol, 2.5\% HPMC), and FIII (2\% carbopol, 3\% HPMC). Gels evaluated for their physical properties include organoleptic, viscosity, $\mathrm{pH}$, homogeneity, scattering power, adhesion and Freezethaw cycling. Then the gel tested antibacterial activity against bacteria Staphylococcus aureus and Pseudomonas aeruginosa by cup-plate diffusion method. The data obtained were analyzed with One Way Anova and LSD with a 95\% confidence level. The results showed that beluntas leaf extract gel meets the organoleptic requirements, homogeneity, good gel adhesion $(>4 \mathrm{sec})$, good gel viscosity (2000-50.000 cps), and good gel pH (4.5-6.5). However, the gel does not meet the requirements of good scattering power $(5-7 \mathrm{~cm})$ and Freeze-thaw cycling. Based on the test results that have been done with some of the parameters above, The best composition of carbopol 940 and HPMC in the beluntas leaf extract gel which has antibacterial activity against Staphylococcus aureus and Pseudomonas aeruginosa is $1 \%$ carbopol and 1.5\% HPMC. The antibacterial activity of the formula is categorized as strong.
\end{abstract}

Keywords: antibacterial, formulation, gel, Pluchea indica (L.), Pseudomonas aeruginosa, Staphylococcus aureus

\footnotetext{
*Corresponding author:

Nanik Sulistyani

Departement of Pharmaceutical Biology, Faculty of Pharmacy, Universitas Ahmad Dahlan

J1.Prof. Dr. Soepomo, S.H.,Warungboto, Umbulharjo, Yogyakarta, Indonesia

Email: naniksulistyani@gmail.com
} 


\section{INTRODUCTION}

Beluntas leaves (Pluchea indica L.)) is one of the native plants of Indonesia that is widespread in several regions in Indonesia. Beluntas leaves contain alkaloids, flavonoids, tannins, essential oils, chlorogenic acid, sodium, potassium, magnesium, and phosphorus, while the roots contain flavonoids and tannins (Mohamad et al., 2011). In addition, beluntas leaves also have the potential to be antibacterial, including at Staphylococcus aureus, Pseudomonas aeruginosa Streptococcus mutants, and Bacillus subtillis (Widyawati et al., 2014). In addition, beluntas leaves also have various potential pharmacological activities, including antioxidants, analgesics, anti-inflammatories, antilarvasida, antibacterial, and diuretic activities. They contain bioactive compounds such as flavonoids, terpenoids, saponins, phenols, quinine, and tannins (Mohamad, 2017). In Manu's research (2013), it was obtained that the inhibitory strength of ethanol extract of beluntas leaves towards Staphylococcus aureus is at a concentration of $60 \%$ of $15.93 \mathrm{~mm}$, Bacillus subtilis at a concentration of $60 \%$ of $14.31 \mathrm{~mm}$, and Pseudomonas aeruginosa at a concentration of $60 \%$ of $15.25 \mathrm{~mm}$. Based on these results, it can be concluded that the antibacterial activity of ethanol extract of beluntas leaves was strong inhibitory strength.

The gel extract of beluntas leaves is very potential to be formulated into topical preparations. One of the effective dosage forms is gel. The gel has become the preference since it has high water content, good penetration power, is easy to wash, is not sticky and greasy, gives a comfortable feeling on the skin (sense of cooling), and can provide a high-speed power in releasing drugs and absorption on the treatment of the skin (Amalia, 2012). The bases used in gel preparations are carbopol 940 and hydroxypropyl methylcellulose (HPMC).

Carbopol base gel preparations are hydrophilic, which will facilitate the process of releasing flavonoids from the base. Carbopol as gelling agent serves to improve the consistency of gel preparations. The selection of carbopol base is because it can easily disperse in water and in small concentrations. It can serve as a gel base with a pretty good viscosity (Balsam and Sagarin, 1970). In contrast, HPMC can form clear gels and it is compatible with other materials and better hydrogelforming materials (Migliozzi et al., 2019). The ready-made gel needs to be evaluated to know the stability of the gel both in terms of chemical and physical condition. The evaluation of gel preparations includes the organoleptic test, the gel viscosity test, $\mathrm{pH}$ test, homogeneity test, scatter power test, adhesion test, and Freeze-thaw cycling test (Dantas et al., 2016; Sowmya, 2015).

This study aims to determine the influence of variations between carbopol gel base 940 and hydroxypropyl methylcellulose (HPMC) on the stability of the physical properties of gel of extract of beluntas leaves (Pluchea indica (L.)) and to know the influence of beluntas leaf extract on antibacterial activities.

\section{MATERIALS AND METHOD Materials}

The material used in this study is beluntas leaves (Pluchea indica (L.)), obtained from the Lamongan area and identified in the Biology Laboratory of Ahmad Dahlan University, Yogyakarta. Gel constituents with pharmacious degree include; hydroxypropyl methylcellulose (HPMC), carbopol 940, triethanolamine (TEA), propylene glycol, methylparaben.

\section{Methods \\ Sample Processing}

Beluntas leaves were weighed, and it obtained weight of $15 \mathrm{~kg}$. The leaves that have been taken, cleaned of dirt and dust by washing them in running water. Leaves that have been washed, drained, winded, and carried out knitting. Then the leaves were dried in the oven at a temperature of $40^{\circ} \mathrm{C}$. The purpose of drying the leaves is to reduce the water content to prevent the occurrence of decay, bacterial growth, to stop the occurrence of enzymatic reactions in plant cells, bacterial work, and chemical changes so that symplicia is obtained that is not easily damaged and can be stored for a long 
time. If the moisture content is high, it can cause the process of mushroom growth. The dried leaves were then pollinated and sifted. The purpose of pollination was to obtain maximum of the active substance due to the area of contact with large solvents. The powder was stored at room temperature in a tightly wrapped glass container, protected from sunlight, and ready for extraction (Mamonto, 2014).

\section{Extraction}

Powder simplicial beluntas leaves weighed as much as $500 \mathrm{~g}$, then macerated with $2 \mathrm{~L}$ ethanol $96 \%$ for $3 \times 24$ hours while occasionally stirred at room temperature, then filtered. The pulp is recoupled with the same method and solvent until the solvent is almost transparent. The filtrate obtained then combined, then evaporated with a rotary evaporator at a temperature of $40-50^{\circ} \mathrm{C}$. The evaporation of the extract is continued on the water bath so that it is obtained the condensed extract (Bahar et al., 2015).

\section{Topical gel formulation beluntas leaf extract Formula}

The formula in this research is a modification that refers to the research of Saraung et al. (2018). Beluntas leaf extract gel formula is made in gel preparations with variations of carbopol $9400.5 \%$ (F0), $1 \%$ (FI), 1.5\% (FII), 2\% (FIII), and HPMC 1\% (F0), 1.5\% (FI), 2.5\% (FII), 3\% (FIII), as presented in Table 1.

Table 1. The gel formula of beluntas leaf extract

\begin{tabular}{lcccc}
\hline \multicolumn{1}{c}{ Materials } & F0 & FI & FII & FIII \\
\hline Beluntas Leaf Extract & - & 15 & 15 & 15 \\
Karbopol 940 & 0.5 & 1 & 1.5 & 2 \\
HPMC & 1 & 1.5 & 2.5 & 3 \\
TEA & 2.5 & 2.5 & 2.5 & 2.5 \\
Propilen glikol & 10 & 10 & 10 & 10 \\
& & & & \\
Metil Paraben & 0.2 & 0.2 & 0.2 & 0.2 \\
Aquadest ad & 100 & 100 & 100 & 100 \\
\hline
\end{tabular}

\section{Topical beluntas leaf extract gel making procedure}

Gel formulation with base combined between HPMC and carbopol 940. The HPMC is developed into hot water for fifteen minutes. Carbopol on different mortar developed with hot water until homogeneous, then added TEA until clear. The developed HPMC is inserted into a mortar contains carbopol and it is stirred until homogeneous. Methyl parabens are dissolved with propylene glycol, mixed into the base, and stirred until homogeneous. Aquadest is added little by little stirs until homogeneous. The extract is added last to the gel, then stirred until homogeneous (Al-Suwayeh et al., 2014; Lane, 2013).

\section{Evaluation of gel preparations Organoleptic test:}

An organoleptic test is conducted visually by observing the shape, color, and smell of gel preparations beluntas leaf extract (Widia, 2012).

\section{Viscosity test}

The gel determined its viscosity with Viscosimeter Brookfield and used spindle no.4 attached to the device, regardless of the flow type. The preparation is put in a glass container, and then the mounted spindle is lowered until the spindle boundary is dipped into the preparation. The tool's speed is mounted at $3 \mathrm{rpm}$ then the scale is read by observing the red needle in a stable position. Viscosity test value based on the SNI is $2000-50.000$ cps (SNI, 1992; Sinko, 2011). 


\section{The pH test}

The $\mathrm{pH}$ measurement is done by using a $\mathrm{pH}$ meter tool. The tool is first calibrated using a neutral buffer solution ( $\mathrm{pH}$ 7.01) and an acidic buffer solution ( $\mathrm{pH} 4.01$ ) until the tool shows the price of the $\mathrm{pH}$. Then the electrodes are washed with axle and dried with a tissue. The samples made a concentration of $1 \%$ that is weighed 1 gram of preparation and dissolved with axle up to $100 \mathrm{~mL}$. Then stir homogeneously. Then the electrodes are dipped in the solution, and the result is recorded. An important $\mathrm{pH}$ test is performed to see the acidity level of the gel preparation so as not to irritate the skin. The $\mathrm{pH}$ test value has fulfilled SNI (1992) at a pH value between 4.5 - 6.5 (Naibaho et al., 2013).

\section{Homogeneity test}

The gel with an amount of $0.5 \mathrm{~g}$ is placed on a transparent glass and then covered with transparent glass and observed the rough grains on the transparent glass. A good gel has no coarse grains (Widia, 2012).

\section{Dispresion test}

A total amount of $0.5 \mathrm{~g}$ of gel is placed on round glass, then another glass is placed on it and left for one minute, then the diameter of the gel spread is measured. After that, the 150 grams gel was added and let stand for 1 minute. The diameter of its spread was observed. The result of the scattering power test of preparation must refer to the SNI standard (1992) that applies 5-7 cm (SNI, 1992; Naibaho et al., 2013).

\section{Adhesion test}

The sticky power test is carried out as much as $1 \mathrm{~g}$ of gel placed above the glass object with one glass object to the other. The gel applied between two glass objects is pressed with a load of $1 \mathrm{~kg}$ for 5 minutes on the test tool. After 5 minutes, the load is removed and is recorded the time when the two objects are detached (Naibaho et al., 2013). The valid stickiness requirements for topical preparations are more than 4 seconds (Mukhlishah et al., 2016).

\section{Freeze-thaw cycling test}

Gel preparations are put in tightly closed glass pots, then frozen at a temperature of $-18^{\circ} \mathrm{C}$ for 24 hours, after which they are thawed at $45^{\circ} \mathrm{C}$ for 24 hours $(1$ cycle). Then place the gel preparation at room temperature for 24 hours. The treatment is repeated in three cycles. Observe the physical changes at the end of the cycle, i.e., $\mathrm{pH}$ test, scatter power, adhesion, and viscosity (Wang and Xie, 2013).

\section{Sterilization tools}

The tools used in this study were cleaned first, then wrapped in opaque paper, then inserted into the autoclave at $121^{\circ} \mathrm{C}$ for 15 minutes (Bahar et al., 2015).

\section{Media preparation}

The media Brain Heart Infusion Broth (BHI-B) is made by weighing 37 grams of media powder and then dissolved in 1 liter of aqua dest while heated and stirred until homogeneous. Media is sterilized in autoclaves at $121^{\circ} \mathrm{C}$ for 15 minutes (Bell et al., 2016; CLSI, 2012).

Mueller-Hinton Agar (MHA) media is made by weighing 38 grams of MHA media powder dissolved into 1 liter of an aquadest while heated and stirred until homogeneous. The media is sterilized in the autoclave at $121^{\circ} \mathrm{C}$ for 15 minutes. Then the MHA media is put in a petri dish as much as $20 \mathrm{~mL}$ and left to harden (Bell et al., 2016; CLSI, 2012). 


\section{Making standard turbidity solution (Solution 0,5 Mc. Farland)}

The Mc Farland standard turbidity of 0.5 is made with a mixture of $\mathrm{H} 2 \mathrm{SO} 41 \%$ of $9.95 \mathrm{~mL}$ and $\mathrm{BaCl} 2$ solution of $1.175 \%$ of $0.05 \mathrm{~mL}$. Then it is whisked until a murky solution is formed. This turbidity is used as a standard for bacterial suspension turbidity test, and it is equivalent to a bacterial density of $10^{8} \mathrm{CFU} / \mathrm{mL}$ (Paputungan et al., 2019).

\section{Bacterial suspension making}

A total of $100 \mu \mathrm{L}$ of bacterial suspension from stock is inserted into $1 \mathrm{~mL}$ of BHI media and incubated at a temperature of $37^{\circ} \mathrm{C}$ for 4-6 hours. Furthermore, it is taken as much as $100 \mu \mathrm{L}$ and diluted with $0.9 \%$ sterile $\mathrm{NaCl}$ until the same turbidity is obtained with $\mathrm{Mc}$ Farland $10^{8} \mathrm{CFU} / \mathrm{mL}$ solution (Bell et al., 2016; CLSI, 2012).

\section{Antibacterial activity testing}

Antibacterial activity test of gel of extract of beluntas leaves is done by Cup-Plate diffusion method. Media Mueller Hilton Agar (MHA) prepared by pouring MHA as much as $25 \mathrm{ml}$ into six Petri dishes in a warm state, left solid. The manufacture of wells is carried out using sterile pipettes on media MHA. Wells are made, given the same distance between wells, to form a good well. The suspension of scratch bacteria on the MHA uses the sterile cotton swab; by swabbing to the entire surface of the media evenly. They are filling the well using a sterile micropipette to fill each well hole. Labeled to each well F0 (negative control) without extract (0.5\% carbopol, 1\% HPMC), F1 with 15\% extract (1\% carbopol, 1.5\% HPMC), F2 with 15\% extract, (1.5\% carbopol, 2.5\% HPMC), and F3 with $15 \%$ extract (2\% carbopol, 3\% HPMC). The positive control used Medi-Klin ${ }^{\circledR}$ Clindamycin phosphate gel $1 \%$. After that, the media is put into an incubator at a temperature of $37^{\circ} \mathrm{C}$ for 24 hours. Antibacterial activity is determined by measuring the diameter of the bland zone using the sarong term (Bahar et al., 2015).

\section{Data Analysis}

The data from beluntas leaf extract activity test on the growth of Staphylococcus aureus and Pseudomonas aeruginosa bacteria, statistically analyzed using One Way Anova and LSD with a 95\% confidence level.

\section{RESULT AND DISCUSSION}

The results showed that the different formulas of carbopol 940 and HPMC in the beluntas leaf extract gel had an effect on all the parameters measured. Formula I which contains $1 \%$ carbopol and $1.5 \%$ HPMC is the best formula based on the organoleptic, viscosity, $\mathrm{pH}$, homogeneity, dispersibility, adhesion, freeze-thaw cycle, and antibacterial activity.

\section{Evaluation of beluntas leaves gel Organoleptic test}

Organoleptic testing is carried out to observe the shape, color, and smell of the gel made. Organoleptic test results can be seen in Table 2.

Figure 1 and Table 2 show the organoleptic test observations of gel preparations conducted during three weeks of storage at room temperature. In formulations (F0), (FI), and (FII) from week-0 to week-3, there was no significant change (smell, dosage shape, and color). In the formulation (FIII) week-0, the preparation smells typical of the extract; thick texture and greenish-brown color. However, there was a significant change in week-1 to week-3. The change that occurred was that the texture of the preparation became thick a bit rigid. The color and texture differences in each formulation are influenced by the various base concentrations of HPMC gel and carbopol. The concentration of HPMC gel base and carbopol is getting smaller, providing an increasingly concentrated color intensity with the addition of the same concentration of extracts in each formula. In addition, the resulting texture or 
shape is also different. The higher the base concentration of HPMC gel and carbopol used, the thicker texture can become (Rajalakshmi et al., 2010). Stable gel properties can be affected by the use of a combination of HPMC and carbopol gel bases. HPMC forms a gel base by adapting the solvent so that the liquid is held back, and it increases fluid containment by forming a compact fluid mass. At the same time, carbopol can easily disperse in water, and in a small concentration, it can serve as a gel base with sufficient viscosity (Migliozzi et al., 2019). The stability of the physical properties of the combination of HPMC and carbopol based on research conducted by (Hasyim et al., 2011), shows the stability of the most optimal physical properties of the gel with the use of HPMC gel base. The variation in the composition of the gelling agent of carbopol 940 and HPMC affected the gel's physical properties and antibacterial activity. A good antibacterial gel is a gel which does not change in texture, smell, and color and has antibacterial activity..

Tabel 2. Organoleptic testing results of beluntas leaves gel (Pluchea indica (L.))

\begin{tabular}{|c|c|c|c|c|c|}
\hline Formulation & Organoleptics & Week 0 & Week 1 & Week 2 & Week 3 \\
\hline \multirow{4}{*}{ F0 } & & Typical & Typical & Typical & Typical \\
\hline & Smell & $\begin{array}{c}\text { HPMC and } \\
\text { karbopol }\end{array}$ & $\begin{array}{c}\text { HPMC and } \\
\text { karbopol }\end{array}$ & $\begin{array}{c}\text { HPMC and } \\
\text { karbopol }\end{array}$ & $\begin{array}{c}\text { HPMC and } \\
\text { karbopol }\end{array}$ \\
\hline & Texture & A bit lumpy & A bit lumpy & A bit lumpy & A bit lumpy \\
\hline & Color & Clear & Clear & Clear & Clear \\
\hline \multirow{3}{*}{ FI } & Smell & $\begin{array}{l}\text { Typical } \\
\text { extracts }\end{array}$ & $\begin{array}{l}\text { Typical } \\
\text { extracts }\end{array}$ & $\begin{array}{l}\text { Typical } \\
\text { Extracts }\end{array}$ & $\begin{array}{l}\text { Typical } \\
\text { extracts }\end{array}$ \\
\hline & Texture & A bit lumpy & A bit lumpy & A bit lumpy & A bit lumpy \\
\hline & Color & $\begin{array}{c}\text { Black } \\
\text { brownish }\end{array}$ & $\begin{array}{c}\text { Black } \\
\text { brownish }\end{array}$ & $\begin{array}{c}\text { Black } \\
\text { Brownish }\end{array}$ & $\begin{array}{c}\text { Black } \\
\text { brownish }\end{array}$ \\
\hline \multirow{3}{*}{ FII } & Smell & $\begin{array}{l}\text { Typical } \\
\text { extracts }\end{array}$ & $\begin{array}{l}\text { Typical } \\
\text { extracts }\end{array}$ & $\begin{array}{l}\text { Typical } \\
\text { Extracts }\end{array}$ & $\begin{array}{l}\text { Typical } \\
\text { extracts }\end{array}$ \\
\hline & Texture & Thick & Thick & Thick & Thick \\
\hline & Color & Brown & Brown & Brown & Brown \\
\hline \multirow{3}{*}{ FIII } & Smell & $\begin{array}{l}\text { Typical } \\
\text { extracts }\end{array}$ & $\begin{array}{l}\text { Typical } \\
\text { extracts }\end{array}$ & $\begin{array}{l}\text { Typical } \\
\text { Extracts }\end{array}$ & $\begin{array}{l}\text { Typical } \\
\text { extracts }\end{array}$ \\
\hline & Texture & Thick & $\begin{array}{c}\text { Thick rather } \\
\text { rigid }\end{array}$ & $\begin{array}{c}\text { Thick rather } \\
\text { rigid }\end{array}$ & $\begin{array}{c}\text { Thick rather } \\
\text { rigid }\end{array}$ \\
\hline & Color & $\begin{array}{l}\text { Greenish } \\
\text { brown }\end{array}$ & $\begin{array}{c}\text { Greenish } \\
\text { brown }\end{array}$ & $\begin{array}{l}\text { Greenish } \\
\text { Brown }\end{array}$ & $\begin{array}{l}\text { Greenish } \\
\text { brown }\end{array}$ \\
\hline
\end{tabular}

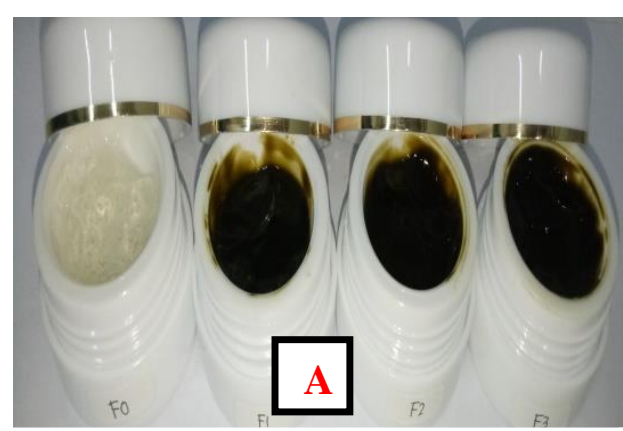

(A) Gel preparation week-0

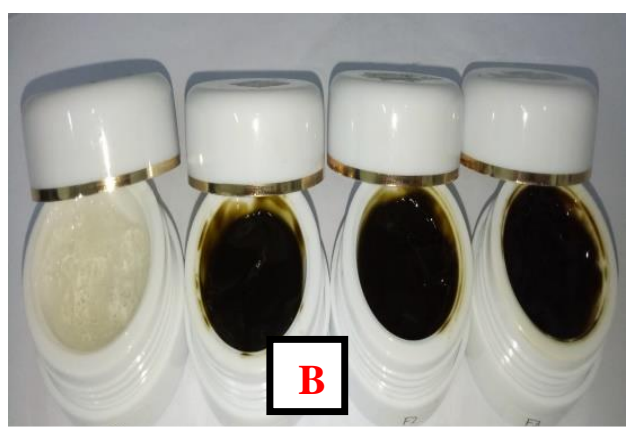

(B) Gel preparation week-3

Figure 1. Observation results of organoleptic of beluntas leaves gel (Pluchea indica (L.)) 


\section{Viscosity testing}

Viscosity testing aims to determine the viscosity value of gel preparations expressed in centipoises (cps) and is related to ease when applied on the skin. The gel is determined viscosity by using a viscometer. The viscometer used is Viscosimeter Brookfield. The results of viscosity testing can be seen in Table 3 .

Table 3. Viscosity, $\mathrm{pH}$, and adhesive power testing results of beluntas leaves gel (Pluchea indica (L.))

\begin{tabular}{cccc}
\hline Formulation & $\begin{array}{c}\text { Viscosity } \\
\text { (cps) }\end{array}$ & pH & $\begin{array}{c}\text { Adhesive } \\
\text { power } \\
\text { (seconds) }\end{array}$ \\
\hline F0 & $11074.85 \pm 67.80$ & $6.24 \pm 0.19$ & $6.40 \pm 0.12$ \\
FI & $23890.18 \pm 197.52$ & $5.97 \pm 0.12$ & $8.38 \pm 0.15$ \\
FII & $31416.82 \pm 1583.61$ & $5.88 \pm 0.21$ & $10.45 \pm 0.07$ \\
FIII & $44467.71 \pm 1085.02$ & $5.74 \pm 0.08$ & $12.70 \pm 0.13$ \\
\hline
\end{tabular}

Based on Table 3, the higher the viscosity of a gel, the more stable the gel will be. It is because it experiences the movement of particles that tend to be more difficult with the viscousness of a gel. The combination of carbopol and HPMC gel bases showed the increased viscosity. The higher the base concentration of carbopol and HPMC gels, the higher the viscosity of the gel. Formula F0 (control (-)), gel without the additional extract has a lower viscosity than other formulas with extract additions. However, all formulas qualify for a better gel preparation viscosity value of $2000-50.000 \mathrm{cps}$ (Sinko, 2011).

\section{pH test}

The $\mathrm{pH}$ testing of preparations is carried out using a $\mathrm{pH}$ meter. The $\mathrm{pH}$ of gel preparations should correspond to the $\mathrm{pH}$ of the skin, which is 4.5-6.5. the $\mathrm{pH}$ test results can be found in Table 3 . statistical test results showed no significant difference in $\mathrm{pH}$ values between the formulas $\mathrm{p}>0.05$. The obtained result showed the largest value of carbopol coefficient has a positive influence compared to HPMC. The higher number of carbopol the more acidic the $\mathrm{pH}$. The higher the concentration of carbopol and the lower the concentration of HPMC in a formula, the more acidic the preparation $\mathrm{pH}$ will be obtained. This is because carbopol is acidic, so that along with the amount increased, the $\mathrm{pH}$ of the preparation is also getting acidic (Dantas et al., 2016; Kaur, 2013). Carbopol when it is added with water will disperse and partially decompose forming hydrogen bonds with water; carbopol will be acidic due to the ionization of the carboxyl group (Migliozzi et al., 2019). It indicates that beluntas leaf gel preparations meet the requirements of $\mathrm{pH}$ test preparations because it is still along with the $\mathrm{pH}$ of the skin (4.5-6.5), so it is safe to use and does not cause irritation to the skin (Naibaho et al., 2013).

\section{Homogeneity test}

Homogeneity tests are carried out to see the homogeneity of the gel created. Testing is carried out by applying gel to the glass object. The gel is said to be homogeneous in the nonexistence of coarse particles. The results of observations of gel preparation homogeneity test are: in week-0 to week-3 shows that, the absence of coarse particles on the glass object, then in the four formulations of gel preparations are declared homogeneous. Gel preparations of each formula shows an even color, so it can be concluded that the four formulas made have a good homogeneity. The homogeneity test results of this gel preparation did not affect the variations towards HPMC and carbopol concentrations on gel homogeneity. Prior research conducted testing of beluntas leaf extract cream with concentrations of $5 \%, 10 \%$, and $15 \%$ showed that the homogeneity of cream preparations before and 
after storage obtained homogeneous dosage results and the absence of coarse grains on the cream (Suru et al., 2019).

\section{Dispersion test}

Gels with good dispersion power will provide a good spread of medicinal ingredients so that the treatment will be more effective. The greater the scattering power, the easier the gel preparation to apply on the skin surface. It is related to the distribution of the active substance in the preparations (Naibaho et al., 2013). HPMC has a positive value coefficient which means it has an effect in increasing gel spread power. The higher number of HPMC, the more scatter power will decrease because the preparation is getting thicker. Meanwhile, carbopol has a negative coefficient which means it has low scattering power.

Scatter power test results showed that the gel formulation with the best scatter power is the formulation (F1) with an average of $4.71 \mathrm{~cm}$. The condition of scattering power for topical preparations is about 5-7 cm (SNI, 1992; Naibaho et al., 2013). However, in this study, the scattering power obtains under the specified terms. This condition is affected by the consistency of the masseuse gel resulting in a less than maximum spread. Differences in scattering power greatly influence the speed of diffusion of the active substance passing through the membrane. The wider the membrane where the preparation spreads, the greater the diffusion coefficient that results in drug diffusion is increasing, so that the greater the dispersion power of preparation better (Kermany, 2010).

\section{Adhesion test}

Based on Table 3, the test results of gel preparation adhesion from beluntas leaf extract showed that the fastest adhesion test result is a gel with carbopol base concentration $0.5 \%$ formula (F0) with an average value of 6.40 seconds. This condition happens because gels with a formula carbopol base concentration of $0.5 \%$ have more water content. The first adhesive power is a gel with a base concentration of 3\% HPMC formula (FIII), with an average value of 12.70 seconds. Due to the higher HPMC levels, the more colloids formed will be and able to increase adhesivity. Reasonable stickiness requirements for topical preparations are more than four seconds (Mukhlishah et al., 2016). Carbopol can form colloids with the addition of water because carbopol condenses water to become thick and sticky. It indicates that testing the adhes to gel beluntas leaves with variations of HPMC and carbopol meets reasonable adhesor requirements due to the adhesiveness produced in more than 1 second. The results of the sticky power test showed that the increasing concentration of HPMC used by each formula, the longer the time attached to the gel. It is because HPMC can form colloids with the addition of hot water. Colloids are formed because the dispersed substances disorbtion of the dispersing medium so that it becomes viscous and sticky, therefore the higher the HPMC levels, the more colloids formed will be and able to increase its adhesion. HPMC is a positive coefficient which means it affects the increasing adhesion while carbopol has a negative coefficient which means to decrease adhesion. This indicates that the adhesivity increases in line with the increase in HPMC concentration because HPMC has a positive effect on increasing adhesivity (Migliozzi et al., 2019)

\section{Freeze-thaw cycling testing}

Freeze-thaw cycling testing is one way to accelerate the evaluation of the physical stability of gel preparations carried out as many as three cycles. Each cycle is stored in the refrigerator at $-18^{\circ} \mathrm{C}$ for 24 hours, then transferred into the climatic chamber at $45^{\circ} \mathrm{C}$ for 24 hours. Then place at room temperature for 24 hours. After each cycle, a physical gel test is done. It includes: $\mathrm{pH}$, scatter power, adhesion, and viscosity.

The results of freeze-thaw cycling for three cycles occurred a significant change to $\mathrm{pH}$ preparations. It is due to the difference in base concentration of HPMC and carbopol used. The higher the concentration of carbopol and the lower the HPMC concentration used, the more acidic the $\mathrm{pH}$ value. It is also affected by extreme temperature differences from storage at a temperature of $18^{\circ} \mathrm{C}$ to a 
temperature of $45^{\circ} \mathrm{C}$ during storage and causes an increasingly acidic pH (Dantas et al., 2016; Kaur, 2013). The evaluation of scattering power after the freeze-thaw cycling test showed significant changes in all formulas. The obtained scatter power value is low and does not meet the specifications of better gel scattering power. It is due to the changes in the resistance of gel preparations, resulting in a change in the consistency of gel preparations (Rajalakshmi et al., 2010). The yield after freeze-thaw cycling showed a significant decrease from before storage, but the obtained adhesion value has still met the requirement of more than 1 second. Decreased adhesion is due to the decreasing viscosity value (Amalia, 2012). Viscosity results after the freeze-thaw cycling test showed significant changes to the formula (F0) and (FI). It is due to the small carbopol concentration and the greater concentration of HPMC used. The use of small concentrations in carbopol causes the resistance of gel preparations to be reduced due to the structure of less three-dimensional colloidal tissue, making it difficult to absorb water for a long time at low-temperature storage. The smaller the concentration of carbopol used in the preparation, the more unstable the preparation in the storing while the preparation with a high concentration of carbopol tends to be more stable in storage (Kermany, 2010).

\section{Antibacterial activity test results}

The testing of antibacterial activity of beluntas leaf extract gel is done by the CupPlate diffusion method. It is done by making well holes filled with gel preparations to be tested. It is incubated at $37 \mathrm{oC}$ for 24 hours. Then it observed the bland zone around the well hole indicates the nonexistence of bacterial growth. The diameter of the bland zone is measured using the length of the funnel by measuring horizontally and vertically and the result has lessened the diameter of the well by $5 \mathrm{~mm}$ (Hanum and Mimiek, 2015). According to Davis Stout, there are several categories of bacterial inhibitory strength, namely bacterial inhibitory strength with $a \geq 20 \mathrm{~mm}$ inhibition diameter as the powerful categories, bacterial inhibitory strength with a diameter of $10-20 \mathrm{~mm}$ including the strong inhibition, bacterial inhibitory strength with an inhibition diameter of 5-10 mm including medium categories, and bacterial inhibitory strength with a $\leq 5 \mathrm{~mm}$ inhibition including weak categories (Rita, 2010).

The test results of Staphylococcus aureus and Pseudomonas aeruginosa antibacterial activity can be observed in Table 4.

Table 4. Staphylococcus aereus and Pseudomonas aeruginosa antibacterial activity test results

\begin{tabular}{cccc}
\hline Formulation & $\begin{array}{c}\text { Staphylococcus } \\
\text { aereus }\end{array}$ & $\begin{array}{c}\text { Pseudomonas } \\
\text { aeruginosa }\end{array}$ & Description \\
\hline Control (+) & $26.60 \pm 0.57$ & $27.00 \pm 1.00$ & Very strong \\
F0 (control (-)) & 0 & 0 & - \\
FI & $16.70 \pm 0.57$ & $17.60 \pm 0.57$ & Strong \\
FII & $16.30 \pm 0.57$ & $15.60 \pm 0.57$ & Strong \\
FIII & $14.60 \pm 0.57$ & $14.30 \pm 0.57$ & Strong \\
\hline
\end{tabular}




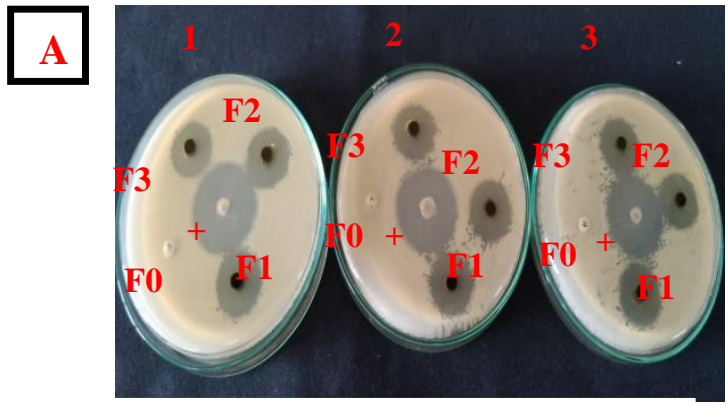

(A) Staphylococcus aereus bacteria

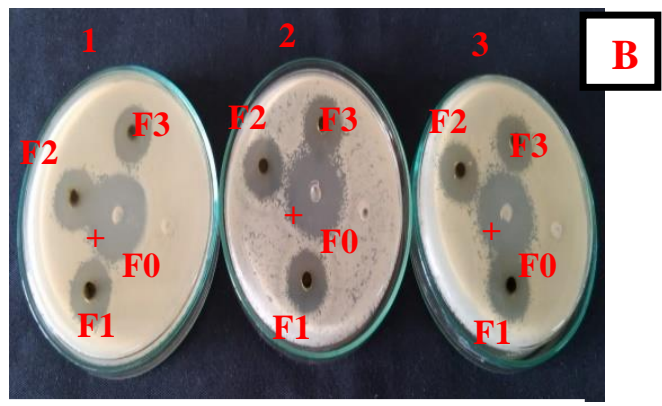

(B) Pseudomonas aeruginosa bacteria

Figure 2. Antibacterial activity test

Description: (A) Staphylococcus aereus bacteria and (B) Pseudomonas aeruginosa bacteria, F0 (control (-) without extract ( $0.5 \%$ carbopol, $1 \%$ HPMC), F1 $15 \%$ extract (1\% carbopol, $1.5 \%$ HPMC), F2 with $15 \%$ extract, (1.5\% carbopol, $2.5 \%$ HPMC), and F3 with $15 \%$ extract (2\% carbopol, $3 \%$ HPMC).

Control (+) Medi-Klin®Clindamycin phosphate gel $1 \%$.

In-gel preparations made, F0 as a control (-) used gel formulations that contain only gel base without the active substance of beluntas leaf extract. Gel base serves as a correction factor because there are preservatives in the form of methyl parabens that may have antibacterial activity. However, the results showed the gel base had no antibacterial activity due to the unless formation of the bland zone. At the same time, other gel formulas formed bland zones. At the control (+) is used Clindamycin phosphate gel $1 \%$ which has a bland power with a very strong categorical. HPMC gel and carbopol with a small concentration and addition of beluntas leaf extract have greater bland power than the one with the base of HPMC gel and carbopol with a large concentration. It has been mixed with beluntas leaf extract resulted in a more minor bland power. It is because the gel base is difficult to diffuse so that the active substance of beluntas leaf extract can not be appropriately separated from the gel base. Thus, the blandness of bacteria is getting smaller. The reduction in blandness value can be correlated with the gel quality to viscosity due to the influence of increasing carbopol and HPMC levels that vary by formula. The greater the levels of carbopol and HPMC will increase the viscosity of preparation, and the greater the viscosity of preparation, the greater the resistance. Thus, it prevents the release of the active substance and results in a decreased taste of gel formulations against bacteria Staphylococcus aureus and Pseudomonas aeruginosa (Sinko, 2011).

Here are some previous studies on beluntas leaf extract in inhibiting bacteria. Manu's research (2013) on "Antibacterial activity of ethanol extract of beluntas leaves against Staphylococcus aureus, Bacillus subtilis, and Pseudomonas aeruginosa" obtained the results of bland power test against Staphylococcus aureus at a concentration of $60 \%$ of $15.91 \mathrm{~mm}$, Bacillus subtilis at a concentration of $60 \%$ of $14.32 \mathrm{~mm}$, and Pseudomonas aeruginosa at a concentration of $60 \%$ of $15.21 \mathrm{~mm}$. Therefore, ethanol extract of beluntas leaves has antibacterial activity in the strong category. Bella's research (2018), showed that ethanolic extract of beluntas leaves can inhibit Staphylococcus aureus bacteria in a row $16.00 \mathrm{~mm}, 17.22 \mathrm{~mm}$, and $18.12 \mathrm{~mm}$ with strong categorical in inhibiting staphylococcus aureus bacteria.

\section{CONCLUSION}

Variations in the concentration of carbopol 940 and HPMC as a gel base for extracts of beluntas (Pluchea indica (L.) Less) leaves affect the physical properties of the gel preparation. The base composition of $1 \%$ carbopol 940 and 1.5\% HPMC is the best formulas with strong antibacterial activity against Staphylococcus aureus and Pseudomonas aeruginosa. 


\section{ACKNOWLEDGEMENT}

Thank you to the Ministry of Research and Technology / National Research and Innovation Agency (Kemenristek/Brin) for the Master Thesis Research Grant fiscal year 2020.

\section{REFERENCES}

Al-Suwayeh, S. A., Taha, E. I., Al-Qahtani, F. M., Ahmed, M. O., \& Badran, M. M. (2014). Evaluation of skin permeation and analgesic activity effects of carbopol lornoxicam topical gels containing penetration enhancer. Scientific World Journal, 2014, 127495. https://doi.org/10.1155/2014/127495

Amalia, F. (2012). Formulasi gel kurkuminoid sebagai anti jerawat dan aktifitas anti bakteri terhadap Staphylococcus aureus [Skripsi]. Purwokerto, Fakultas Farmasi, Universitas Muhammadiyah Purwokerto

Bahar, M. A., Alam, G., Manggau, M. A., Mufidah, \& Suparman. (2015). Bioassay-guided fractination of antimitotic compound from ongkea cortex (Mezzettia parviflora Becc) towards sea urchin eggs. Journal of Tropical Pharmacy and Chemistry, 3(1), 49-54. https://doi.org/10.25026/jtpc.v3i1.88

Balsam, M., \& Sagarin, E. (1970). Cosmetic Science and Technology (4th ed.). New York: John Wiley $\&$ Sons

Bell, S. M., Carter, J. N., Hanrahan, I. W., \& Nguyen, T. T. (2013). Antibiotic Susceptibility Testing By the Cds Method a Manual for Medical and. April, 93.

Bella, A. A. (2018). Uji aktivitas antibakteri kombinasi ekstrak etanolik daun beluntas (Pluchaea indica Less.) dan meniran (Phyllanthus niruri L.) terhadap bakteri Staphylococcus aureus. [Skripsi]. Surakarta, Universitas Setia Budi.

CLSI (Clinical and Laboratory Standards Institute). (2012). Performance standards for antimicrobial disk susceptibility tests; Approved. M02-A11, 32(1), 17-22.

Dantas, M., Reis, S., Damasceno, C., Rolim, L., Rolim-Neto, P., Carvalho, F., L, Q.-J., \& J, D. S. A. (2016). Development and evaluation of stability of a gel formulation containing the monoterpene borneol. The Scientific World Journal, 2016, 7394685. https://doi.org/10.1155/2016/7394685

Hanum, P. A., \& Mimiek, M. (2015). Pengaruh Variasi Kadar Gelling Agent HPMC terhadap sifat fisik dan aktivitas antibakteri sediaan gel ekstrak etanolik daun kemangi (Ocimum basilicum L. forma citratum Back.). Majalah Farmaseutik, 11(2), 307-315

Hasyim N, Faradiba, \& A, B. (2011). Formulasi gel sari belimbing wuluh (Averrhoa bilimbi L. ). Majalah Farmasi Dan Farmakologi, 15((1)), 5-9

Kaur, L. P. (2013). Topical gel: A recent approach for novel drug delivery. Asian Journal of Biomedical and Pharmaceutical Sciences, 3(17), 1-5

Kermany, B. P. (2010). Carbopol hydrogels for topical administration: Treatment of wounds (Thesis). University of Troms $\emptyset$

Lane, M. E. (2013). Skin penetration enhancers. International Journal of Pharmaceutics, 447(1-2), 12-21. https://doi.org/10.1016/j.ijpharm.2013.02.040

Mamonto, S. I. (2014). Aktivitas antioksidan ekstrak kulit biji buah pinang Yaki (Areca vestiaria giseke) yang di ekstraksi secara soklet. Pharmacon, 3(3), 263-272. https://doi.org/10.35799/pha.3.2014.5443

Manu, R. R. S. (2013). Aktivitas antibakteri ekstrak etanol daun beluntas (Pluchea indica L.) Tehadap Stapylococcus aureus, Bcillus subtilis dan Pseudomonas aeruginosa. Calyptra: Jurnal Ilmiah Mahasiswa Universitas Surabaya, 2(1), 1-10

Migliozzi, S., Angeli, P., \& Mazzei, L. (2019). Gelation kinetics of non-aqueous Carbopol dispersions. Colloids and Surfaces A: Physicochemical and Engineering Aspects, 577, 84-95. https://doi.org/10.1016/j.colsurfa.2019.05.051

Mohamad Irfan Fitriansyah, R. B. I. (2017). Eview: profil fitokimia dan aktivitas farmakologi Baluntas (Pluchea indica L.). Unsrat Press, 16(2), 337-346

Mohamad, S., Zin, N. M., Wahab, H. A., Ibrahim, P., Sulaiman, S. F., Zahariluddin, A. S. M., \& Noor, Composition of carbopol ... (Alvionida et al., ) 
S. S. M. (2011). Antituberculosis potential of some ethnobotanically selected Malaysian plants. Journal of Ethnopharmacology, 133(3), 1021-1026. https://doi.org/10.1016/j.jep.2010.11.037

Mukhlishah, N. R. I., Sugihartini, N., \& Yuwono, T. (2016). Daya iritasi dan sifat fisik sediaan salep minyak atsiri bunga cengkih (Syzigum aromaticum) pada basis hidrokarbon. Majalah Farmaseutik, 12(1), 372-376

Naibaho, O. H., Yamlean, P. V. Y., \& Wiyono, W. (2013). Pengaruh basis salep terhadap formulasi sediaan salep ekstrak daun Kemangi (Ocimum sanctum L.) pada kulit punggung Kelinci yang dibuat infeksi Staphylococcus aureus. Jurnal Ilmiah Farmasi-UNSRAT, 2(02), 27-34

National Committee for Clinical Laboratory Standards. (1993). Performance standards for antimicrobial disk susceptibility tests. approved standard M2-A5. National Committee for Clinical Laboratory Standards, Villanova Pa., M2-A5(1), 17-22

Paputungan, A. N., Lolo, W. A., \& Jayanto, I. (2019). Aktivitas antibakteri dan analisis KLTbioautografi dari fraksi daun Manggis (Garcinia mangostana L.). PHARMACON, 8(3), 525. https://doi.org/10.35799/pha.8.2019.29326

Rajalakshmi G, Damodharan, N., Bhai, C. V. K. V., \& Janardhanreddy, R. P. (2010). Formulation and evaluation of clotrimazole and ichtammol ointment. International Journal of Pharma and Biosciences, 1(4), 6-16

Rita, W. S. (2010). Isolasi, identifikasi, dan uji aktivitas antibakteri senyawa golongan triterpenoid pada rimpang temu putih (Curcuma zedoaria (Berg.) Roscoe). Jurnal Kimia, 4(1), 20-26

Saraung, V., Yamlean, P. V, \& Citraningtyas, G. (2018). Pengaruh variasi basis karbopol dan HPMC pada formulasi gel ekstrak etanol daun tapak kuda (Ipomoea pes-caprae (L.) R. Br. dan uji aktivitas antibakteri terhadap Staphylococcus aureus. Pharmacon, 7(3), 220-229

Sinko, P. J. (2006). Farmasi Fisika dan Ilmu Frmasetika Martin (5th ed.). Jakarta: Penerbit Buku Kedokteran EGC

SNI. (1992). SNI 06-2588-1992 Deterjen sintetik cair pembersih tangan. Jakarta: Badan Standarisasi Nasional.

Sowmya J, D. (2015). Topical gels: a recent approach for novel drug delivery. -. International Journal of Health Sciences and Research (IJHSR), 5(10), 302-312

Suru, E., Yamlean, P., \& Lolo, W. (2019). Formulasi dan uji efektivitas krim antibakteri ekstrak etanol daun beluntas (Pluchea indica Less.) terhadap bakteri Propionibacterium acnes. Pharmacon, 8((2)), 209-218. https://doi.org/10.35799/pha.8.2019.29256

Wang, L., Xie, B., Xiong, G., Wu, W., Wang, J., Qiao, Y., \& Liao, L. (2013). The effect of freezethaw cycles on microstructure and physicochemical properties of four starch gels. Food Hydrocolloids, 31(1), 61-67. https://doi.org/10.1016/j.foodhyd.2012.10.004

Widia, W. (2012). Formulasi sediaan gel ekstrak etanol daun lidah buaya (Aloe vera L.) sebagai anti jerawat dengan basis sodium alginate dan aktivitas antibakterinya terhadap Staphylococcus epidermidis [Skripsi]. Surakarta, Fakultas Farmasi, Universitas Muhammadiyah Surakarta.

Widyawati, P. S., Budianta, T. D. W., Kusuma, F. A., \& Wijaya, E. L. (2014). Difference of solvent polarity to phytochemical content and antioxidant activity of Pluchea indicia Less leaves extracts. International Journal of Pharmacognosy and Phytochemical Research, 6(4), 850-855 